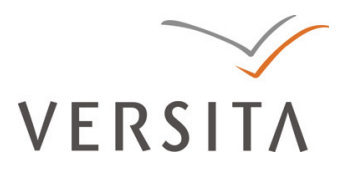

Folia Oeconomica Stetinensia

DOI: $10.2478 / \mathrm{v} 10031-012-0019-4$

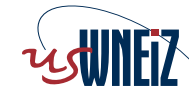

Wydzial Nauk Ekonomicznych i Zarządzania
Uniwersytetu Szczecińskiego

\title{
PROFITABILITY OF REDUCTION OF SPEED AND FUEL CONSUMPTION FOR SEA GOING BULK CARRIERS
}

Dariusz Doskocz, MSc Eng.

Polska Żegluga Morska P.P.

Plac Rodła 8, 70-419 Szczecin, Poland

e-mail:ddoskocz@gmal.com

Received 13 July 2012, Accepted 7 November 2012

\begin{abstract}
Extremely high price of oil and consequently fuel used by sea going bulk carriers combined with very low freight rates - BDI (Baltic Dry Index), the main index of the freight market dropped from almost 12,000 to about 700 during the last four years - forced ship owners and operators to re-calculate speed and consumption parameters of their fleet. On the basis of speed/consumption parameters taken directly from ships, the average cost of marine fuel IFO and the freight market reported by The Baltic Exchange the author calculated the profitability of the reduction of speed for typical bulk carriers from about 26,000 to 80,000 DWT.

Despite the extremely low freight market and very high price of fuel the savings due to the reduction of fuel consumption are generally consumed by time loss. The speed reduction may be profitable only for the group of the largest of the analyzed ships but every time ship operators have to take into consideration such consequences as the weather risk, positioning for the next employment, charter party obligations etc.
\end{abstract}

Keywords: sea freight, marine fuel cost, Baltic Dry Index.

JEL classification: L11, L91, R40. 


\section{Introduction}

Extremely high price of oil and consequently fuel used by sea going bulk carriers combined with very low freight rates - BDI (Baltic Dry Index), main index of freight market dropped from almost 12,000 to about 700 during last four years - forced ship owners and operators to recalculate speed and consumption parameters of their fleet. Fuel is the main cost in every calculation of commercial voyage and any deduction in this position may give additional profits or - in very low market - minimize losses. Unfortunately, lower consumption may be obtained only by the deduction of main engine revolution, and consequently speed, resulting in longer voyage.

In this paper expected freight rates and incomes are calculated basing on the Baltic Dry Index for chosen dates while a bunker price is taken directly from respective suppliers reports. By comparing bunker saving and loss due to longer voyage with specific speed/consumption parameters of each analyzed group of ships the author calculates at what level of freight market rates, affecting daily profits of sea voyage, the reduction of fuel consumption equals the loss of time.

\section{Baltic Dry Index}

The profitability and the commercial results of operating bulk (liquid and dry) carriers are strictly connected to the level of freight market. Both sides of commercial negotiations - a ship operator and a charterer - always check freight or daily time charter value of a ship connected to a correspondent segment of the market. The most important institution that publishes indices used in shipping industry is The Baltic Exchange, a membership organization based in London providing daily information based on real fixtures. There are 26 physical routes collected in six groups for ships from 28,000 DWT (called handy size) to 172,000 DWT (called cape size) bulk carriers making up the Baltic Indexes, covering main sectors of shipping market. General index - the BDI (Baltic Dry Index) is created as an aggregate of four components:

- BCI (Baltic Exchange Capesize Index) based on ships 150,000-172,000 DWT,

- BPI (Baltic Exchange Panamax Index) based on ships 74,000 DWT,

- BSI (Baltic Exchange Supramax Index) based on ships 54,000 DWT,

- BHSI (Baltic Handy Size Index) based on ships 28,000 DWT.

Additionally, all indexes are suplemented by the Daily Summary of the Baltic Exchange Time Charter Routes. Those parameters are given in USD and present daily average hire for ships from each group and may be also treated as a daily value of a ship - the amount per day a ship owner could earn from charterers. 
After the record May 2008 when the BDI reached 11,793² the index fell rapidly to the level below 1,000 (663 in December 2008) $)^{2}$ and despite some temporary rises it continues to stay very low. Consequently, the daily hire rate dropped and ship owners noted very large decline in the daily ship value. For example a panamax size ship could earn almost 100,000 USD daily in 2008 while at the beginning of 2012 the market reported the average of 12,000 USD with some drops to about 6,000 USD. Initially the decline of freight rates was partially offset by the decreasing fuel price but from 2009 the price of oil has been instantly rising. Comparing BDI indices as shown in Figure 1 with oil price as presented in Figure 2 we can see that the general trend lines for the analyzed period diverge. Those facts forced ship owners to take steps in order to reduce costs - and the main cost in shipping is fuel.

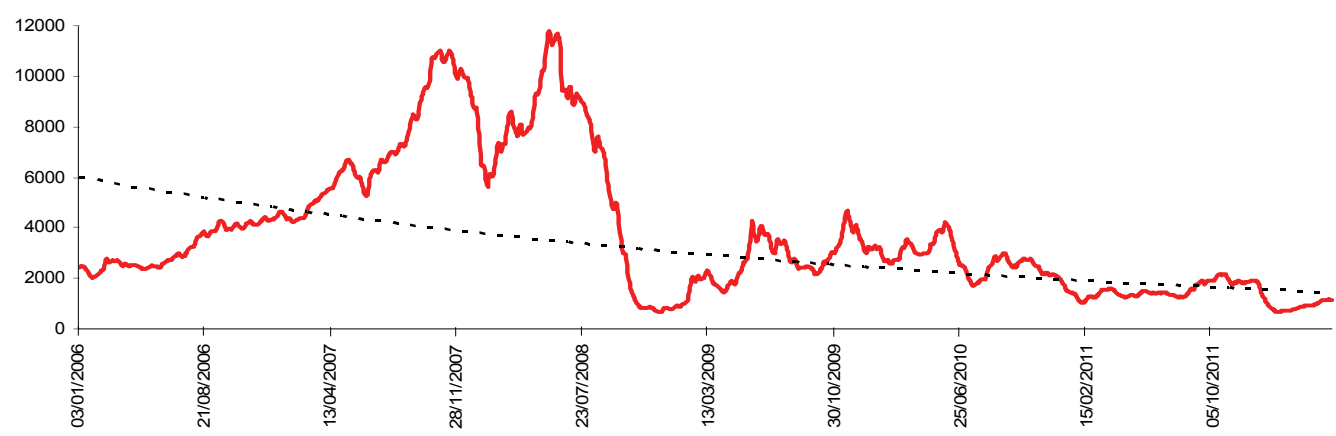

Fig. 1. Baltic Dry Index (BDI)

Source: The Baltic Exchange.

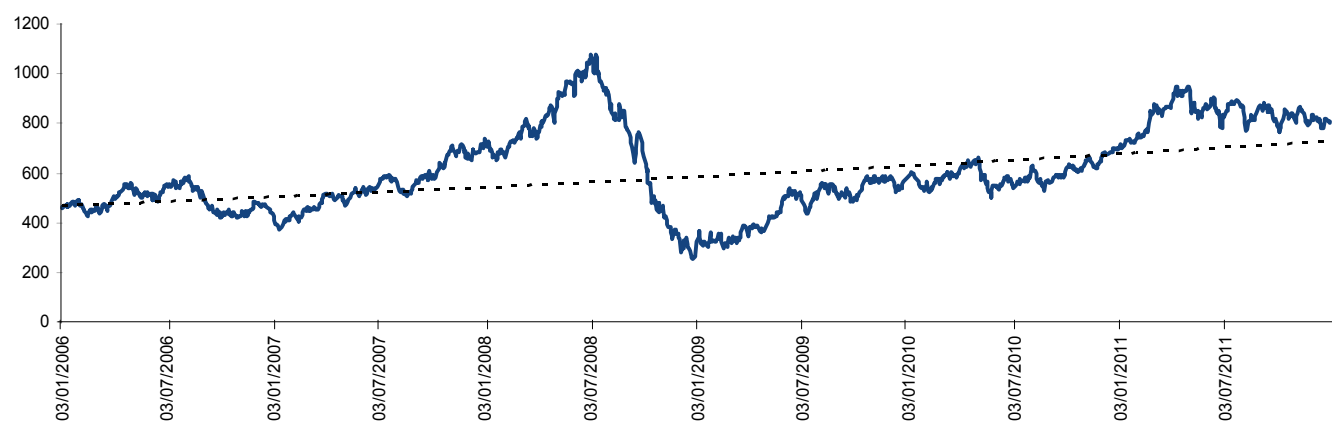

Fig. 2. Brent oil price (USD per mt

Source: London Stock Exchange. 


\section{Marine fuel}

All bulk carriers are powered by marine fuel engines. Depending on their size and engine type the ships taken into account in this study use from about eighteen to over forty metric tons of intermediate marine fuel (IFO) and the cost of daily fuel consumption may reach 2830,000 USD. The example of a price level is shown in Table 1.

Table 1. Bunker price for chosen places as on December 30, 2011

\begin{tabular}{|l|c|c|}
\hline Port or bunkering place & IFO price USD per mt & IFOls price USD per mt \\
\hline Rotterdam & 621 & 674 \\
\hline Antwerp & 625 & 677 \\
\hline Great Belt & 639 & 700 \\
\hline Gdańsk & 637 & 737 \\
\hline St.Petersburg & 415 & 495 \\
\hline Gibraltar & 640 & 717 \\
\hline
\end{tabular}

Source: own research.

Additionally, some ships also use marine diesel oil (MDO) for generators but this element can not be reduced, a ship's demand for electricity during the sea passage may be considered as flat and not connected to speed. The price of marine fuel is different in every port or bunkering place located outside the port limit, for example at Danish Straits or Gibraltar, but it is connected to crude oil price (see Figure 3).

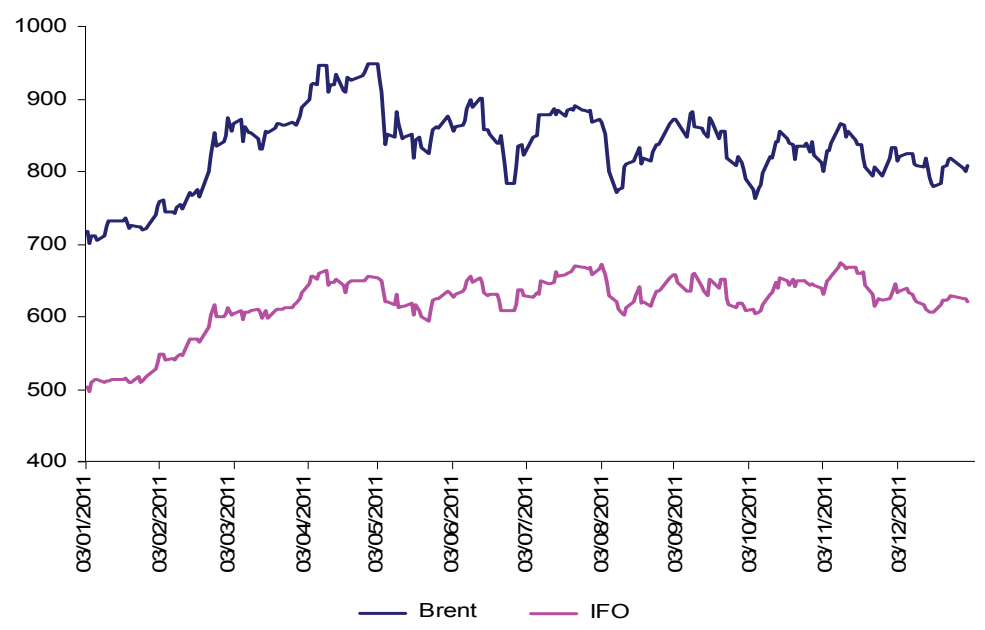

Fig. 3. Brent oil and IFO price in Rotterdam in USD per metric ton Source: own study based on officially reported prices. 
Major ports, like Rotterdam, Hamburg, Szczecin or Sankt Petersburg, have proper shore facilities or specialized barges for fuel supply, called in shipping bunkers.

For example in 2011 the sales volume of IFO at Rotterdam, the biggest bunker port in Europe was 11.6 million metric tons ${ }^{3}$. Compared to Rotterdam the fuel prices in most European ports are higher with the exception of the Russian ports.

Additionally, in some regions a ship cannot use ordinary fuel. According to the International Convention for the Prevention of Pollution from Ships, 1973-1978 (MARPOL) - in Northern Europe and, from August 2012, the US Coast ships as well have to use fuel with reduced sulfur content. Standard IFO contains up to $3.5 \%$ of sulfur while the reduced one (IFOls - IFO low sulfur) only up to $1.0 \%{ }^{4}$. This obligation results in higher bunker cost, approximately 45-80 USD per metric ton (see Table 1).

\section{Data}

All data are taken directly from ships operating worldwide and owned by Polska Zegluga Morska P.P. Real speed and consumption depend on many parameters and in the sea conditions it is very hard to obtain comparable data. According to a good shipping practice any ship owner is required to maintain the declared speed and consumption 'in good weather condition', which means the wind on the Beaufort scale not higher than 4 and the sea condition of $3^{5}$. These weather conditions are considered as not affecting the ship's speed and consumption parameters.

Additionally, sea streams, fuel quality, gales and sea traffic should be comparable. In reality, however, such conditions rarely happen.

Table 2. The main parameters of the analyzed ships

\begin{tabular}{|l|c|c|c|c|c|c|}
\hline \multicolumn{1}{|c|}{ Type } & $\begin{array}{c}\text { Number } \\
\text { of ships }\end{array}$ & DWT & $\begin{array}{c}\text { 'Normal' } \\
\text { speed }\end{array}$ & $\begin{array}{c}\text { 'Normal' } \\
\text { consumption }\end{array}$ & $\begin{array}{c}\text { 'Eco' } \\
\text { speed }\end{array}$ & $\begin{array}{c}\text { 'Eco' } \\
\text { consumption }\end{array}$ \\
\hline Handy 1 & 3 & 26,300 & 12.7 & 20.0 & 11.8 & 18.0 \\
\hline Handy 2 & 6 & 33,700 & 12.5 & 22.5 & 11.0 & 19.5 \\
\hline Panamax & 6 & 73,400 & 13.4 & 33.0 & 12.0 & 26.5 \\
\hline Kamsarmax & 4 & 79,600 & 13.8 & 38.2 & 12.2 & 31.2 \\
\hline
\end{tabular}

Speed in knots (nautical mile per hour). Consumption in metric tonnes per day.

Source: own study.

Ships are constructed according with precise parameters of the main engine, the hull, the propeller etc. and despite theoretical tables and curves created for newly built vessels it is very hard to predict the changes in consumption being the effect of reduced speed. In commercial 
conditions ships have to sail directly to their destination without any unfounded delay and it does not make sense to test the reduced speed. Nevertheless, after about three years of collecting data and the support from the ships' Captains the author managed to get necessary information from 19 ships grouped in four types of sister vessels. For greater transparency of the presented data all parameters are shown rounded to the nearest hundred or respective to the nearest decimal and averaged within groups.

\section{Method}

Basing on the speed/consumption parameters taken directly from the ships, the average cost of marine fuel IFO and the freight market reported by main worldwide ship brokers the author calculated the profitability of the reduction of speed for typical bulk carriers from about 26,000 to 80,000 DWT, described as 'handy' to 'kamsarmax' size. Every deduction of speed resulting in a longer voyage and time loss has also its economic weight described in shipping as a daily ship's value or a time-charter equivalent. To achieve the profitability level the saved fuel value should be at least equal to the loss of time and to extra fuel consumed due to longer voyage:

$$
C \cdot z-C \cdot z^{\prime} \cdot p=W \cdot(p-1)
$$

where:

$p=\frac{v}{v}$

$W$ - Daily time charter equivalent (the 'value' of a ship),

$C$ - Fuel price,

$z$ - Daily fuel consumption - full speed,

$z^{`}$ - Daily fuel consumption - reduced (eco) speed,

$v$ - Full speed,

$v^{`}$ - Reduced (eco) speed.

Consequently:

$$
W=C \cdot \frac{z-p \cdot z}{p-1}
$$

In the equation (2) the author analyzes only the impact of fuel cost/longer voyage on a final voyage result represented as the daily 'value' of ship. Other costs, like the crew, port services, insurance and general management are not taken into consideration and treated as flat ${ }^{6}$ - these items reduce the ship Owner's profits but do not affect their income being the result of freight rate or hire level. 
Calculation is made on the basis of one day of voyage in US dollars and may be easily compared to the respective Baltic Exchange Time Charter Routes.

\section{Results and conclusions}

By means of the formula (2) we can check at what level of the daily value of a ship its owner or operator should reduce speed in order to get higher profits per day. The results for chosen fuel prices are presented in Table 3 and compared with the respective Baltic Exchange Time Charter Routes. The reported values and indices are averaged for all the routes and prepared for specified ships and should be treated as reference point only - in reality the voyages results and the ship descriptions may be different.

The average ship's value in December 2011 as reported by The Baltic Exchange for December 2011:

BPI USD 13,748.72,

BSI USD 12,913.71,

BHSI USD 8,563.46.

The BPI index refers to th panamax and kamsarmax types of the analyzed ships while BHSI and BSI relate to the handy 1 and handy 2 types.

Speed reduction can be cost effective when a calculated daily ship's value for a particular voyage is lower than the limit value presented in Table 3.

Table 3. Limit of a daily ship's value for chosen fuel prices

\begin{tabular}{|l|c|c|c|c|}
\hline & Handy 1 & Handy 2 & Panamax & Kamsarmax \\
\hline $\begin{array}{l}\text { 415.00 } \\
\text { (IFO St.Petersburg } \\
30.12 .2011)\end{array}$ & 3,412 & 1,038 & 12,124 & 9,204 \\
\hline $\begin{array}{l}\text { 618.50 } \\
\text { (IFO mean price } \\
\text { Rotterdam for 2011) }\end{array}$ & 4,933 & 1,500 & 17,529 & 13,305 \\
\hline $\begin{array}{l}\text { 738.00 } \\
\text { (IFOls Gdańsk } \\
\text { 30.12.2011) }\end{array}$ & 6,068 & 1,845 & 21,560 & 16,365 \\
\hline $\begin{array}{l}\text { 820.00 } \\
\text { (IFOls Mediterranean } \\
\text { Sea March 2012) }\end{array}$ & 6,742 & 2,050 & 23,956 & 18,184 \\
\hline
\end{tabular}

Fuel price in USD per metric ton. Ship's daily value in USD. Bolded items - a result higher than the respective level of time charter reported by The Baltic Exchange.

Source: own study. 
Comparing the results from Table 3 with the respective indices it is easy to conclude that despite the extremely low freight marker and the very high level of fuel price the savings due to the deduction of fuel consumption are generally consumed by the time loss. Only for the group of the largest ships the speed reduction may be profitable but every time the ship's operator has to take into consideration other factors, such as weather risk, positioning for the next employment, a charter party obligation etc. ${ }^{7}$

The presented above calculation and conclusion refer only to the analyzed types of ships. Other ships, even similar in size but with a different engine, propeller or technical characteristic may give different results. This paper presents the method of calculating the profitability of reducing speed and consumption and shows a general trend on the freight and bunker market.

\section{Notes}

1 Baltic Exchange daily report 20.05.2008.

2 Baltic Exchange daily report 5.12.2008.

3 Bunkerwold 16.01.2012 issued by Petromedia Ltd.

4 MARPOL (2011), Convention Annex VI Regulation 14.

5 See Wilson (2010), p. 88.

6 See Kubicki (1994), p. 80.

7 Williams (1996), p. 16.

\section{References}

Baltic Exchange daily report 20.05.2008.

Baltic Exchange daily report 5.12.2008.

Bunkerwold 16.01.2012 issued by Petromedia Ltd.

Wilson, J.F. (2010). Carriage of Goods by Sea, 7th ed. Pearson Education Ltd.

Williams, H. (1996). Chartering Documentation, 3rd ed. London: Lloyd's of London Press Ltd.

Kubicki, J. (1994). Ekonomika i Organizacja Transportu Morskiego. Gdynia: Wyższa Szkoła Morska.

MARPOL - Consolidaed Edition (2011). London: International Maritime Organization. 